\title{
Potensi Pemberian Cod Liver Oil (CLO) Pada Pakan Komersial Terhadap Jumlah Total Asam Lemak Omega 3 Dan Omega 6 Di Daging Udang Galah (Macrobrachium Rosenbergii)
}

\section{Potential Of Giving Cod Liver Oil (CLO) Commercial Feed On To The Total Amount Of Omega 3 And Omega 6 Fatty Acid In Meat Giant Freshwater Prawn (Macrobrachium Rosenbergii)}

\author{
Hartik $^{1^{*}}$, Boedi Setya Rahardja ${ }^{2}$, Agustono $^{2}$ \\ ${ }^{1}$ Budidaya Perairan, Fakultas Perikanan dan Kelautan Universitas Airlangga, Surabaya 60115 \\ ${ }^{2}$ Departemen Manajemen Kesehatan Ikan dan Budidaya Perairan, Fakultas Perikanan dan Kelautan Universitas \\ Airlangga, Surabaya 60115 \\ *Hartiktg@gmail.com
}

\begin{abstract}
Abstrak
Asam lemak omega 3 dan omega 6 adalah asam lemak tak jenuh yang termasuk kedalam golongan Poly Unsaturated Fatty Acid (PUFA) dan juga termasuk dalam kelompok asam lemak esensial. Asam lemak omega 3 dan omega 6 tidak dapat disintesis sendiri oleh tubuh, sehingga perlu adanya suplai asam lemak omega 3 dan omega 6 di makanan yang dikonsumsi. Fungsi dari asam lemak omega 3 dan omega 6 secara fisiologis yaitu sebagai sumber penting dalam menunjang pertumbuhan dan kelangsungan hidup krustacea. Penelitian ini bertujuan untuk mengetahui potensi pemberian Cod Liver Oil (CLO) pada pakan komersial terhadap jumlah total asam lemak omega 3 dan omega 6 di daging udang galah (Macrobrachium rosenbergii). Metode penelitian yang digunakan adalah percobaan dengan Rancangan Acak Lengkap sebagai rancangan percobaan. Perlakuan yang digunakan adalah kandungan Cod Liver Oil (CLO) yang berbeda, yaitu P0 (0\%), P1 (3\%), P2(6\%), P3 (9\%), P4(12\%) masing-masing perlakuan diulang sebanyak 4 kali. Parameter utama yang diamati adalah jumlah total asam lemak omega 3 dan omega 6 di daging udang galah. Parameter penunjang yang diamati adalah parameter kualitas air. Analisis data menggunakan analisis of varian (ANOVA) dan untuk mengetahui perlakuan terbaik dilakukan uji jarak berganda Duncan. Hasil penelitian pemberian Cod Liver Oil (CLO) menunjukkan berbeda nyata $(\mathrm{P}<0,05)$ terhadap jumlah total asam lemak omega 3 tetapi tidak berbeda nyata $(\mathrm{P}>0,05)$ dengan jumlah total asam lemak omrga 6 di daging udang galah (Macrobrachium rosenbergii). Jumlah total asam lemak omega 3 pada perlakuan P0 (0\%) berbeda nyata dengan perlakuan P2 (6\%), P3 (9\%) dan P4 (12\%), tetapi tidak berbeda nyata dengan perlakuan P1. Jumlah total asam lemak omega 6 pada perlakuan P0 (0\%) tidak berbeda nyata dengan perlakuan P1 (3\%), P2 (6\%), P3 (9\%) dan P4 (12\%).
\end{abstract}

Kata kunci : Asam lemak omega 3, Asam lemak omega 6, Cod Liver Oil (CLO), udang galah (Macrobrachium rosenbergii)

Fatty acids omega 3 and omega 6 unsaturated fatty acids are included into class Poly Unsaturated Fatty Acid (PUFA) and is also included in a group of essential fatty acids.Fatty acids omega 3 and omega 6 can not be synthesized by the body, so it is necessary to supply fatty acids omega 3 and omega 6 in the food consumed. This study aims to determine the potential for the provision of Cod Liver Oil (CLO) on a commercial feed to the total amount of fatty acids omega 3 and omega 6 in the flesh of giant fresh water prawn (Macrobrachium rosenbergii). The method used is experiment with completely randomized design as the experimental design. The treatment used is the content of Cod Liver Oil (CLO) that is different, that P0 (0\%), P1 (3\%), P2 (6\%), P3 (9\%), P4 (12\%) of each treatment was repeated 4 times. The main parameters measured were the number of total fatty acids omega 3 and omega 6 in meat prawns. Supporting parameters measured were water quality parameters. Analysis of data using analysis of variance (ANOVA) and to determine the best treatment Duncan's multiple range test. The results of the research granting Cod Liver Oil (CLO) showed significantly $(\mathrm{P}<0.05)$ of the total amount of omega 3 fatty acids but not significantly different $(\mathrm{P}>0.05)$ with the total amount of fatty acids omrga 6 in the meat giant fresh water prawn (Macrobrachium rosenbergii). The total amount of omega 3 fatty acids in the treatment of P0 (0\%) was significantly different from P2 treatment (6\%), P3 (9\%) and P4 $(12 \%)$, but not significantly different from P1 treatment. The total amount of fatty acids in the treatment omega 6 P0 (0\%) did not differ significantly with treatment P1 (3\%), P2 (6\%), P3 (9\%) and P4 (12\%).

Key words : omega 3 fatty acids, omega 6 fatty acids, Cod Liver Oil (CLO), freshwater prawn (Macrobrachium rosenbergii)

65|J I P K Vol.9 No.1, A prill 2017 Diterima/submitted:25 Desember 2016 D is etujui/accepted:9 Maret 2017 


\section{PENDAHULUAN}

\section{Latar Belakang}

Berdasarkan data FAO (2011), udang galah merupakan salah satu produk unggulan komoditas perikanan air tawar yang memiliki nilai gizi yang tinggi dan banyak diminati oleh konsumen dari berbagai negara di dunia. Permintaan akan udang galah sendiri mengalami peningkatan setiap tahun (Sari, 2008). Produksi udang di Indonesia pada tahun 2011 mencapai 400.385 ton, kemudian meningkat menjadi 457.600 ton pada tahun 2012 dan tahun 2013 target produksi udang ditetapkan sebesar 660.000 ton (KKP, 2013).

Udang mengandung banyak nutrisi yang baik jika dikonsumsi manusia, namun udang juga mempunyai kandungan kolesterol yang cukup tinggi. Rata-rata kandungan kolesterol pada berbagai jenis udang yaitu sebesar 152 mg/100 gram (Krzynowek dan Panunzio, 1989). Udang galah sendiri yaitu mengandung kolesterol sebesar 139 mg/100 gram (Bragagnolo and Rodriguez-Amaya, 2001). Menurut Sukarsa (2004), asam lemak omega 3 dapat menurunkan kadar kolesterol (lipida) dalam darah, yaitu dengan cara menghambat pembentukan protein dan trigliserida dalam VLDL sehingga kadar
VLDL/LDL dan kolesterol menjadi menurun.

Udang memiliki kemampuan yang terbatas dalam elongasi dan desaturasi linolenat menjadi Eicosapentaenoat Acid (EPA) dan Docosaheksaenoat Acid (DHA). Sintesa EPA dan DHA termasuk asam lemak esensial bagi udang untuk menjadi fungsi selulernya, sehingga dibutuhkan suplai asam lemak omega 3 dari makanan yang dikonsumsinya (Halver, 1989). Keberhasilan budidaya udang harus memperhatikan kebutuhan komposisi asam lemak omega 3 pada pakan (Yustianti dkk., 2013). Kandungan omega 3 pada daging udang galah (Macrobrachium rose2nbergii) yaitu sebesar 26\% dan omega 6 sebesar 15\% (Bragagnolo and Rodriguez-Amaya, 2001) - Salah satu bahan yang dapat meningkatkan kadar omega 3 dalam daging udang galah (Macrobrachium rosenbergii) adalah Cod Liver Oil. Minyak hati ikan kod (Cod Liver Oil) mengandung asam lemak tak jenuh omega 3 yang secara fisiologis merupakan sumber penting dalam menunjang pertumbuhan dan kelangsungan hidup krustacea (D’ Abramo and Sheen, 1993).

Penelitian tentang penggunaan Cod Liver Oil (CLO) pada udang galah untuk

66|J I P K Vol.9 No.1, A pril2 017 Diterima/submitted:25 Desember 2016 Disetujui/accepted:9 Maret 2017 
mengetahui potensinya dalam mempengaruhi jumlah total asam lemak omega 3 dan omega 6 belum banyak dilakukan, sehingga perlu dilakukan penelitian tentang potensi pemberian Cod Liver Oil (CLO) pada pakan komersial terhadap jumlah total asam lemak omega 3 dan omega 6 di daging udang galah (Macrobrachium rosenbergii).

\section{METODOLOGI PENELITIAN}

\section{Tempat dan Waktu Penelitian}

Penelitian ini di lakukan di UPPB Prigi. Analisis cod liver oil dan analisis asam lemak omega 3 dengan omega 6 dilakukan di Unit Layanan Pengujian (ULP) Fakultas Farmasi, Universitas Airlangga Surabaya. Penelitian ini dilaksanakan pada bulan Juni 2016.

\section{Peralatan Penelitian}

Alat yang digunakan dalam penelitian ini antara lain 20 buah akuarium berukuran 40x20x25 $\mathrm{cm}^{3}$, aerator, selang aerasi, selang sipon, batu aerasi, bak plastik besar, gelas ukur, timbangan digital, termometer, $\mathrm{pH}$ meter, DO meter, amoniak test kit.

\section{Bahan Penelitian}

Bahan utama yang digunakan dalam penelitian adalah udang galah (Macrobrachium rosenbergii) jantan dengan berat 10 gram. Udang galah didapatkan dari Unit Pengelola Perikanan Budidaya (UPPB) Prigi, Trenggalek, Jawa Timur. Bahan yang digunakan antara lain cod liver oil (CLO) merk Baby's DHA dan pakan komersial merk Feng Li.

\section{Prosedur Kerja}

\section{A. Persiapan Wadah Pemeliharaan}

Tahap awal dalam melakukan persiapan yaitu menyiapkan akuarium yang akan digunakan dengan ukuran 40x20x25 $\mathrm{cm}^{3}$. Akuarium yang akan digunakan dicuci dengan detergen sampai bersih, kemudian dibilas, selanjutnya dikeringkan di bawah sinar matahari. Masing-masing akuarium diisi dengan air tawar dengan volume 7 liter per akuarium, setelah itu dipasang dengan selang aerasi pada masing-masing akuarium.

\section{B. Persiapan Udang Galah}

\section{(Macrobrachium rosenbergii)}

Udang galah sebanyak 140 ekor yang telah diukur panjang dan berat tubuhnya ditebar ke dalam bak dengan kepadatan 7 ekor per akuarium serta diberi aerasi. Sebelum diberi perlakuan, udang galah perlu aklimatisasi untuk beradaptasi. Aklimatisasi bertujuan untuk mencegah terjadinya shock pada suatu organisme bila dipindahkan dari suatu lingkungan ke dalam lingkungan yang baru (Suyanto dan Takarina, 2009). 


\section{Penyediaan Pakan Udang Galah} (Macrobrachium rosenbergii)

Pakan yang diberikan untuk udang galah berupa pakan komersial merk Feng Li yang ditambahkan Cod Liver Oil dan tepung tapioka sebagai perekat. Formulasi analisis pakan per perlakuan dapat dilihat pada Tabel 4.1 sedangkan komposisi pakan dapat dilihat pada Tabel 4.2 di bawah ini.

Semua bahan-bahan penyusun pakan disiapkan dan ditimbang sesuai pencampuran Cod Liver Oil dengan pakan komersial yaitu dengan cara CLO di campurkan ke tepung tapioka setelah itu baru ke pakan komersial. Bahan-bahan tersebut diaduk dengan menggunakan blender dengan tujuan agar CLO tercampur secara merata ke pakan sehingga menjadi homogen. Bahan-bahan yang telah tercampur dicetak kembali menjadi bentuk pelet. Pakan dioven dengan suhu $50^{\circ} \mathrm{C}$ selama 24 jam. Tujuan pengovenan yaitu

Tabel 4.3 Kandungan Cod Liver Oil (CLO)

\begin{tabular}{lc}
\hline \multicolumn{1}{c}{ Asam lemak } & Cod Liver Oil (\%) \\
\hline Omega 3 & \\
1. ETE (Eicosatrienoic Acid) & 2,123 \\
2. DHA (Docosahexaenoic Acid) & 10,596 \\
3. HTA (Hexadecatrienoic Acid) & 0,774 \\
4. EPA (Eicosapentaenoic Acid) & 8,5 \\
Omega 6 & \\
1. AA (Arachidonic Acid) & 0,218 \\
2. LA (Linoleat Acid) & 2,35 \\
Omega 9 & \\
1. Oleat & 22,929 \\
2. Eicosenoic & 13,48 \\
3. Eruic & 7,59 \\
\hline
\end{tabular}

Sumber : Hasil Laboratorium dari Unit Layanan Pengujian (ULP) Fakultas Farmasi Universitas Airlangga Surabaya (2016)

dosis yang ditentukan. Pakan komersial digiling terlebih dahulu agar menjadi bentuk tepung kemudian ditambahkan Cod Liver Oil serta dicampurkan dengan tepung tapioka yang dilarutkan air hangat. Teknik untuk mengurangi kadar air serta menambah daya simpan pakan. Pakan yang sudah jadi dianalisa proksimat untuk mengetahui kandungan nutrisi pakan. 
Tabel 4.1 Formulasi dan Kandungan Nutrisi Pakan per Perlakuan Berdasarkan dari Hasil Perhitungan

\begin{tabular}{lccccc}
\hline \multirow{2}{*}{ Komposisi (\%) } & \multicolumn{5}{c}{ Perlakuan } \\
\cline { 2 - 6 } & P0 & P1 & P2 & P3 & P4 \\
\hline Pakan komersial & 100 & 100 & 100 & 100 & 100 \\
Tepung tapioka & 2 & 2 & 2 & 2 & 2 \\
Cod Liver Oil & 0 & 3 & 6 & 9 & 12 \\
Total & 102 & 105 & 108 & 111 & 114 \\
BK (\%) & 89,1363 & 86,8181 & 84,6287 & 82,5577 & 80,5956 \\
Abu (\%) & 12,7695 & 12,4046 & 12,0601 & 11,7341 & 11,4253 \\
PK (\%) & 39,25 & 38,1285 & 37,0694 & 36,0675 & 35,1184 \\
LK (\%) & 4,91124 & 7,46527 & 9,87741 & 12,1592 & 14,3208 \\
SK (\%) & 1,97118 & 1,91486 & 1,86167 & 1,81135 & 1,76368 \\
BETN (\%) & 30,2941 & 29,4286 & 28,6111 & 27,8378 & 27,1053 \\
AIR & 10,7843 & 10,639 & 10,5017 & 10,3719 & 10,2489 \\
Omega 3 & 9,489 & 15.464 & 16,605 & 19,259 & 19,802 \\
Omega 6 & 17,716 & 12.462 & 9,903 & 7,849 & 7,174 \\
\hline
\end{tabular}

Keterangan : Formulasi analisis pakan berdasarkan dari hasil perhitungan

Kandugan Cod Liver Oil dapat dilihat pada

Tabel 4.3.

\section{Pemeliharaan Udang Galah}

\section{(Macrobrachium rosenbergii)}

Udang galah yang sudah diseleksi berdasarkan ukuran dan jenis kelaminnya dimasukkan ke dalam akuarium setelah itu dilakukan aklimatisasi dengan tujuan agar udang galah tersebut beradaptasi dengan lingkungan yang baru. Udang galah ditebar dengan kepadatan 7 ekor per akuarium pemeliharaan berdasarkan penelitian Fatagar (2014).

\section{E. Pemberian Pakan Udang Galah} (Macrobrachium rosenbergii)
Pakan buatan yang digunakan adalah pelet ikan komersial udang galah. Menurut Mitra et al. (2005) frekuensi pemberian pakan yang diberikan pada udang galah sebanyak $5 \%$ dari biomasaa udang galah pada masa pertumbuhan dengan kadar protein 35-37 \%. Frekuensi pemberian pakan yaitu sebanyak dua kali dalam sehari pada 08.00 WIB dan 16.00 WIB.

\section{F. Penyiponan}

Penyiponan pada media udang galah dilakukan setiap hari untuk menjaga kualitas air (Muthalib, 2004), penyiponan dilakukan setelah dua jam pemberian pakan. Penyiponan ini bertujuan agar sisa- 
Tabel 4.2 Kandungan Nutrisi Bahan Pakan

\begin{tabular}{cc}
\hline Kandungan & Pakan komersial Feng Li (\%) \\
\hline BK & 89 \\
Abu & 13 \\
PK & 40 \\
LK & 5 \\
SK & 2 \\
BETN & 29 \\
AIR & 11 \\
\hline
\end{tabular}

sisa pakan buatan maupun sisa-sisa metabolisme ikan dapat dikeluarkan sehingga tidak terjadi penumpukan dan pembusukan dalam air media.

\section{G. Pergantian Air}

Menurut penelitian Muthalib (2004), penggantian air pada udang galah dilakukan setiap tiga hari sekali sebanyak 20-30 \%. Pergantian air menggunakan air yang telah diendapkan dan diaerasi selama dua hari. Proses penggantian tersebut dilakukan dengan cara mengurangi ketinggian air hingga habis dan selanjutnya ditambahkan air hingga volume seperti semula.

\section{H. Pengukuran Kualitas Air}

Pengukuran kualitas air meliputi pengukuran suhu dengan menggunakan termometer, $\mathrm{pH}$ dengan menggunakan $\mathrm{pH}$ meter, oksigen terlarut dengan DO meter dan amonia dengan amoniak test kit. Pengukuran kualitas air dilakukan setiap

Tabel 5.1 Rata-rata dan Standar Deviasi (SD) Jumlah Total Asam Lemak Omega 3 di Daging Udang Galah (Macrobrachium rosenbergii)

\begin{tabular}{ccc}
\hline \multirow{2}{*}{ Treatment } & Jumlah total omega $3 \pm$ SD (\%) & Transformation $(\sqrt{\mathbf{y}+\mathbf{0 , 5}) \pm}$ \\
\hline $\mathrm{P}_{0}$ & $5,53^{\mathrm{a}} \pm 1,33$ & $2,839^{\mathrm{a}} \pm 0,287$ \\
$\mathrm{P}_{1}$ & $5,57^{\mathrm{ab}} \pm 0,75$ & $2,856^{\mathrm{ab}} \pm 0,157$ \\
$\mathrm{P}_{2}$ & $7,17^{\mathrm{bc}} \pm 0,92$ & $3,174^{\mathrm{bc}} \pm 0,174$ \\
$\mathrm{P}_{3}$ & $7,23^{\mathrm{bc}} \pm 0,96$ & $3,185^{\mathrm{bc}} \pm 0,177$ \\
$\mathrm{P}_{4}$ & $7,47^{\mathrm{c}} \pm 1,23$ & $3,337^{\mathrm{c}} \pm 0,232$ \\
\hline
\end{tabular}

Keterangan : Superskrip yang berbeda pada kolom yang sama menunjukkan ada perbedaan yang nyata $(\mathrm{p}<0,05)$ 
hari sekali (Altun et al., 2005).

\section{Parameter Penelitian}

Parameter utama yang diamati adalah asam lemak omega 3 dan omega 6 . Parameter pendukung dari penelitian ini adalah kualitas air meliputi suhu, oksigen terlarut, amoniak dan $\mathrm{pH}$.

\section{Analisis Data}

Data yang diperoleh dari hasil penelitian ini kemudian akan dianalisis menggunakan ANOVA (analysis of Variance) untuk mengetahui pengaruh setiap perlakuan, sesuai dengan rancangan yang digunakan yaitu Rancangan Acak Lengkap (RAL). Jika dari analisis diketahui bahwa perlakuan menunjukkan pengaruh yang berbeda nyata atau berbeda sangat nyata, maka untuk membandingkan perlakuan mana yang menghasilkan hasil terbaik dilanjutkan dengan Uji Duncan
(Kusriningrum, 2015).

\section{HASIL DAN PEMBAHASAN}

Hasil penelitian didapatkan nilai jumlah total asam lemak omega 3 di daging udang galah (Macrobrachium rosenbergii) berkisar antara 2,839\% 3,337\%. Data rata-rata jumlah total asam lemak omega 3 didaging udang galah (Macrobrachium rosenbergii) dapat dilihat pada Tabel 5.1.

Berdasarkan hasil perhitungan analisis data dengan Anava menunjukkan bahwa terdapat perbedaan yang nyata $(\mathrm{p}<0,05)$ terhadap angka dari jumlah total asam lemak omega 3 di daging udang galah (Macrobrachium rosenbergii). Selanjutnya setelah dilakukan uji jarak berganda Dunca's 5\% dapat dilihat bahwa perlakuan P0 berbeda nyata dengan

Tabel 5.2 Rata-rata dan Standar Deviasi (SD) Jumlah Total Asam Lemak Omega 6 di Daging Udang Galah (Macrobrachium rosenbergii).

\begin{tabular}{ccc}
\hline Treatment & Jumlah total omega 6 \pm SD (\%) & $\begin{array}{c}\text { Transformation }(\sqrt{\mathbf{y}+\mathbf{0 , 5}) \pm} \\
\text { SD (\%) }\end{array}$ \\
\hline $\mathrm{P}_{0}$ & $9,40^{\mathrm{a}} \pm 3,18$ & $3,56^{\mathrm{a}} \pm 0,5492$ \\
$\mathrm{P}_{1}$ & $9,73^{\mathrm{a}} \pm 3,19$ & $3,59^{\mathrm{a}} \pm 0,5498$ \\
$\mathrm{P}_{2}$ & $10,09^{\mathrm{a}} \pm 2,88$ & $3,65^{\mathrm{a}} \pm 0,4397$ \\
$\mathrm{P}_{3}$ & $10,09^{\mathrm{a}} \pm 2,88$ & $3,84^{\mathrm{a}} \pm 0,323$ \\
$\mathrm{P}_{4}$ & $11,59^{\mathrm{a}} \pm 1,03$ & $3,90^{\mathrm{a}} \pm 0,149$
\end{tabular}

Keterangan : Superskrip yang sama pada kolom yang sama menunjukkan tidak ada perbedaan yang nyata $(\mathrm{p}>0,05)$ 
perlakuan P2, P3 dan P4, tetapi tidak berbeda nyata dengan perlakuan P1. Sedangkan P4 tidak berbeda nyata dengan perlakuan P2 dan P3, tetapi berbeda dengan P0 dan P1. Sehingga hasil rata-rata dari nilai jumlah total omega 3 terbaik ditunjukkan pada perlakuan P4 yaitu sebesar 3,337\%.

Jumlah total asam lemak omega 3 terendah yaitu sebesar 2,839 \% yang terdapat pada perlakuan (P0) dengan penambahan Cod Liver Oil (CLO) 0\% pada pakan komersial, sedangkan jumlah total asam lemak omega 3 tertinggi yaitu pada perlakuan (P4) sebesar 3,337\% dengan penambahan Cod Liver Oil (CLO) sebesar $12 \%$.

Hasil penelitian menunjukkan bahwa jumlah total asam lemak omega 6 di daging udang galah (Macrobrachium rosenbergii) berkisar antara 3,56\% 3,90\%. Data rata-rata jumlah total asam lemak omega 6 di daging udang galah (Macrobrachium rosenbergii) dapat dilihat pada Tabel 5.2 di atas.

Hasil analisis varian dari pengolahan data jumlah total asam lemak omega 6, menunjukkan bahwa tidak terdapat perbedaan yang nyata $(\mathrm{p}>0,05)$ terhadap jumlah total asam lemak omega 6 di daging udang galah (Macrobrachium rosenbergii). Hasil uji jarak berganda Duncan's menunjukkan bahwa P0 tidak berbeda nyata $(\mathrm{p}>0,05)$ dengan $\mathrm{P} 1, \mathrm{P} 2, \mathrm{P} 3$ dan P4.

Jumlah total asam lemak omega 6 yang tertinggi didapatkan dari perlakuan P4 yaitu sebesar 3,90\% dengan penambahan Cod Liver Oil (CLO) 12\%, sedangkan terendah yaitu sebesar 3,56\%

Tabel 5.3 Nilai Kisaran Parameter Kualitas Air Selama Pemeliharaan 30 Hari

\begin{tabular}{llcc}
\hline No & Parameter & Satuan & Kisaran \\
\hline 1. & Suhu & ${ }^{\circ} \mathrm{C}$ & $28-29$ \\
2. & Oksigen terlarut (DO) & $\mathrm{mg} / \mathrm{l}$ & $6-7$ \\
3. & $\mathrm{pH}$ & - & $6,5-7,5$ \\
4. & Amonia & $\mathrm{mg} / \mathrm{l}$ & $0,02-0,75$ \\
\hline
\end{tabular}


yang terdapat pada perlakuan P0 dengan penambahan Cod Liver Oil (CLO) 0\%.

Berdasarkan hasil analisis data penelitian didapatkan rata-rata jumlah total asam lemak omega 3 di daging udang galah (Macrobrachium rosenbergii) setiap perlakuan yang diberi Cod Liver Oil dengan dosis yang berbeda-beda setelah dilakukan transformasi data yaitu sebagai berikut, rata-rata P0 2,839 $\pm 0,287 \%$; rata-rata $\mathrm{P} 1$ 2,856 \pm 0,157 \%; rata-rata $\mathrm{P} 2$ $3,174 \pm 0,174 \%$; rata-rata P3 3,185 \pm 0,177 \% dan rata-rata P4 3,337 + 0,232\%.

Berdasarkan dari nilai rata-rata jumlah total asam lemak omega 3 dapat dilihat bahwa terdapat perbedaan yang nyata $(\mathrm{p}<0,05)$ diantara perlakuan P0, P1, P2, P3 dan P4. Namun pada uji jarak berganda Duncan's terlihat P0 dan P1 menunjukkan superskrip berbeda dengan P4 sehingga menunjukkan bahwa pada perlakuan P4 memiliki potensi lebih baik dalam meningkatkan jumlah total asam lemak omega 3 di daging udang galah (Macrobrachium rosenbergii), jika dibandingkan dengan perlakuan P0 dan P1, mungkin itu semua dikarenakan oleh pemberian dosis Cod Liver Oil yang rendah yaitu sebesar 0\% pada perlakuan P0 dan 3\% pada perlakuan P1. Hal ini terlihat dari rata-rata jumlah total asam lemak omega 3 antara P0, P1, P3, dan P4 yang menunjukkan angka yang tidak berbeda jauh. Menurut Ichwanda (2015) dosis pemberian Cod Liver Oil pada pakan yang dapat meningkat kandungan derivate asam lemak omega 3 di daging udang vaname yaitu sebesar 9\%.

\section{Pemberian Cod Liver Oil pada} pakan komersial yang diberikan ke udang galah dengan dosis yang semakin meningkat mengakibatkan jumlah total asam lemak omega 3 juga mengalami peningkatan. Hal ini sesuai dengan pendapat Cuzon et al., (2003) yang menyatakan bahwa kandungan asam lemak yang terkandung dalam daging udang adalah cerminan dari asam lemak yang dikonsumsinya, namun dengan demikian jenis pakan yang sama yang diberikan tidak dapat menjamin samanya kandungan dan kualitas asam lemak yang dikonsumsi udang. Hal ini dikarenakan sifat alamiah asam lemak, khususnya asam lemak tidak jenuh yang sangat mudah teroksidasi. Adanya perbedaan cara penanganan pada pakan (misalnya cara pengolahan, penyimpanan, dan pengangkutan) dapat menyebabkan komposisi dan kualitas asam lemak pada pakan menjadi berbeda (Petawi, 1996).

Berdasarkan hasil analisis data penelitian didapatkan rata-rata jumlah total asam lemak omega 6 di daging udang 73|J I P K V ol.9 No.1, A pril 2017 Diterima/submitted:25 Desember 2016 Disetujui/accepted:9 Maret 2017 
galah (Macrobrachiumrosenbergii) setiap perlakuan yang diberi Cod Liver Oil dengan dosis yang berbeda-beda sebagai berikut, rata-rata P0 3,56 $\pm 0,5492 \%$; ratarata $\mathrm{P} 13,59 \pm 0,5498 \%$; rata-rata $\mathrm{P} 2$ 3,65 $\pm 0,4397 \%$; rata-rata P3 $3,84 \pm 0,323 \%$ dan rata-rata $\mathrm{P} 43,90 \pm 0,149 \%$.

Hasil dari uji statistik tersebut menunjukkan bahwa tidak adanya perbedaan yang nyata $(\mathrm{p}>0,05)$ antara perlakuan P1, P2, P3, dan P4. Jumlah total asam lemak omega 6 tertinggi yaitu pada perlakuan P4 dan yang terendah pada perlakuan P0. Perlakuan P0 dosis Cod Liver Oil yang ditambahkan ke pakan yaitu sebesar 0\%, sedangkan P4 yaitu sebesar 12\%. Hasil tersebut menunjukkan bahwa dosis Cod Liver Oil yang tinggi paling banyak meningkatkan jumlah total asam lemak omega 6 di daging udang galah (Macrobrachium rosenbergii). Peningkatan kandungan asam lemak dipengaruhi oleh tingkat pemberian Cod Liver Oil. Hal ini sesuai dengan pendapat Zaitsev et al. (1969) dalam petawi (1996) menyatakan bahwa komposisi daging udang sangat bervariasi tergantung pada udang tersebut, disamping pengaruh spesies, kandungan pakannya, tingkat umur, musim dan habitat.

Jumlah total asam lemak omega 6 di perlakuan P0 (kontrol) mengandung asam lemak tak jenuh lebih rendah dibandingkan dengan perlakuan P1, P2, P3 dan P4. Hal ini disebabkan karena jumlah total asam lemak omega 6 di daging udang galah dari perlakuan kontrol (P0) tidak cukup jumlahnya untuk melakukan proses metabolisme lebih lanjut yaitu elongasi yang berseling dengan desaturasi sehingga menghasilkan jumlah total asam lemak omega 6 yang lainya. Sesuai dengan pernyataan Linder (1991), akan terjadi kompetisi pemakaian $\Delta 6$ desaturase dalam proses desaturasi dua kelompok asam lemak esensial yaitu asam lemak omega 3 dan omega 6, dimana kompetisi tersebut akan dimenangkan oleh kelompok yang jumlahnya lebih besar.

Nilai kisaran suhu selama penelitian berkisar antara $28-29^{\circ} \mathrm{C}$. Hal ini sesuai dengan pendapat Cahyono (2011) yang menyatakan bahwa suhu yang baik untuk pemeliharaan udang galah yaitu berkisar antara $25^{\circ} \mathrm{C}-32^{\circ} \mathrm{C}$. Ikan dapat tumbuh secara normal apabila berada pada perairan dengan kisaran suhu yang sesuai. Perubahan suhu yang terlalu drastis dapat menimbulkan gangguan terhadap laju respirasi, aktifitas jantung dan metabolisme.

Derajat keasaman atau $\mathrm{pH}$ merupakan ukuran konsentrasi ion hidrogen yang menunjukkan suasana asam

74 |J I P K V o l.9 N o.1, A p ril 2017 Diterima/submitted:25 Desember 2016 Disetujui/accepted:9 Maret 2017 
atau basa suatu perairan. Dalam budidaya udan ggalah $\mathrm{pH}$ memiliki peranan yang penting dalam proses fisiologisnya. Hasil pengukuran nilai $\mathrm{pH}$ selama penelitian berkisar antara 6,5-8. Hal ini sesuai pernyataan Erlangga (2012) pH optimal bagi udang galah berkisar 6,0-8,5. Nilai pH yang rendah dapat mengganggu pertumbuhan dan kelangsungan hidup udang, karena dapat menyebabkan udang menjadi stres dan kerapas udang menjadi lembek.

Hasil pengukuran Dissolved Oxygen (DO) atau oksigen terlarut selama penelitian berkisar antara 6-7 mg/l . Hal ini sesuai dengan pendapat Cahyono (2011) yang menyatakan bahwa kadar DO minimal untuk budidaya udang galah adalah $4 \mathrm{mg} / \mathrm{L}$ sedangkan DO maksimal adalah 8 mg/L. Menurut Boyd (1982), kandungan oksigen terlarut merupakan salah satu faktor paling penting dalam sistem perairan dan mutlak diperlukan untuk respirasi atau pernafasan. DO yang rendah dalam perairan dapat menyebabkan kematian dan lambatnya pertumbuhan udang.

Hasil pengukuran amonia $\left(\mathrm{NH}_{3}\right)$ selama penelitian yaitu berkisar antara 0.02-0.75 mg/l. Hal ini sesuai dengan pendapat New (2002) yang mengatakan amoniak untuk udang galah berkisar 0-0,3.
Perbedaan ini dipengaruhi oleh sisa pakan, sesuai pernyataan Hadie dan Hadie (2002) perubahan amoniak dapat disebabkan oleh suhu, pH dan pakan. Kandungan amonia di dalam perairan dapat dikontrol dengan cara melakukan pergantian air. Kondisi air dengan kandungan amonia yang tinggi akan berpengaruh terhadap kondisi fisiologis udang sehingga untuk mengurangi resiko peningkatan kandungan amonia dilakukan penyifonan sisa pakan dan feses setiap pagi hari.

\section{KESIMPULAN DAN SARAN}

Berdasarkan hasil penelitian mengenai potensi pemberian Cod Liver Oil pada pakan komersial terhadap jumlah total asam lemak omega 3 dan omega 6 di daging udang galah (Macrobrachium rosenbergii) didapatkan kesimpulan bahwa pemberian Cod Liver Oil (CLO) dengan dosis 6\% pada pakan komersial memiliki potensi dalam meningkatkan jumlah total asam lemak omega 3 di daging udang galah (Macrobrachium rosenbergii). Pemberian Cod Liver Oil (CLO) dengan dosis $0 \%$ - $12 \%$ pada pakan komersial tidak memiliki potensi dalam meningkatkan jumlah total asam lemak omega 6 di daging udang galah (Macrobrachium rosenbergii). 
Saran yang bisa diberikan dalam penelitian mengenai pengaruh pemberian Cod Liver Oil (CLO) pada pakan komersial terhadap jumlah total asam lemak omega 3 dan omega 6 di daging udang galah (Macrobrachium rosenbergii) sebagai berikut : Berdasarkan hasil penelitian untuk dapat menaikkan jumlah total asam lemak omega 3 di daging udang galah perlu ditambahkan Cod Liver Oil (CLO) dengan dosis 6\%. Perlu dilakukan penelitian lebih lanjut mengenai penambahan dosis Cod Liver Oil (CLO) mulai dari 6\% terhadap kenaikan jumlah total asam lemak omega 3 dan omega 6 di daging udang galah.

\section{DAFTAR PUSTAKA}

Altun, T., N. Tekelioglu., E. Nevsat and Y. Sagat. 2005. Some Growth Parameters on European Eel (Anguilla anguilla L., 1758) Fed with Different Feeds. Journal of Fisheries and Aquatic Sciences, 22(1-2) : 215219.

Bragagnolo, N. and Rodriguez-Amaya, D. B. 2001. Total Lipid, Cholesterol, and Fatty Acids of Farmed Freshwater Prawn (Macrobrachium rosenbergii ) and Wild Marine Shrimp (Penaeus brasiliensis, Penaeus schimitti, Xiphopenaeus kroyeri ). Journal of Food Composition and Analysis. 14, 359369.
Cahyono, B. 2011. Buku Terlengkap Budidaya Udang Galah. Pustaka Mina. Jakarta.

Cuzon, G. Addison. L, Gabriela. G, Carlos. S, dan J, Guillaume. 2003. Nutrition of litopenaeus vanname reared in tanks or in ponds.elsevier. aquaculture 235 (2004) 513-551.

D’ Abramo, L. R. and S. S. Sheen. 1993. Polyunsaturated Fatty Acid Nutrition in Juvenil Freshwater Prawn Macrobrachium rosenbergii. Aquaculture, 115 : 63-86.

Erlangga, E. 2012. Meraup Untung dari Budi Daya Udang Galah pada Kolam Air Tawar. Pustaka Agro Mandiri. Tangerang Selatan. hal 6-49.

FAO (Food and Agriculture organization of the United Nations). 2011. Culture Aquatic Species Information Programme Macrobrachium rosenbergii. Food Agriculture Organization of the United Nations: Fisheries and Aquaculture Department. Pp 12.

Fatagar, S. H. 2014. Jumlah Konsumsi Pakan Udang Galah (Macrobrachium rosenbergii) yang Diberi Pakan Atraktan Berbeda. Skripsi. Budidaya Perairan. Fakultas Perikanan dan Ilmu Kelauta. Institut Pertanian Bogor. Bogor. hal. 3.

Hickling, C. F. 1971. Fish Culture. Faber and Faber. London. 317 pp.

Kementrian Kelautan dan Perikanan. 2013. Indonesia Fisheries Statistic Index. http://www.kkp.go.id/index.php/arsi p/c/9199/Produksi-Udang-BisaCapai-660.000-Ton-pada-2013/. 13 Februari 2016. 1 hal.

Kusriningrum, R. S. 2012. Perancangan Percobaan. Airlangga University Press. Surabaya. Hal 16-17.

Linder, M. C. 1991. Nutrition and Metabolism. Of Fats. (Maria C Linders Eds). In Nutritional Biochemistry And Metabolism. 
Connecticuti Aplton And Lange. Pp. 51-83.

Mitra, G., D. N Chattopadhyay and P. K. Mukhopadhyay. 2005. Nutrition and Feeding in Freshwater Prawn (Macrobrachium rosenbergii) Farming. Journal Aqua Feeds Formulation and Beyond, Vol 2 (1) : 17-19.

Muthalib, A. 2004. Pengaruh Lama Pemberian Aromatase Inhibitor melalui Pakan terhadap Nisbah Kelamin Udang Galah. Skripsi. Teknologi dan Manajemen Akuakultur. Fakultas Perikanan dan Ilmu Kelautan. Institut Pertanian Bogor. Bogor. hal. 13.

New, M.B. 2002. Farming Freshwater Prawns a Manual for The Culture of The Giant River Prawn Macrobrachium rosenbergii. FAO Fisheries, United Kingdom.

Petawi, A. 1996. Pengaruh Habitat Terhadap Kandungan Asam Lemak Omega-3 dan Kolesterol pada Udang Windu (Penaeus monodon Fab). Skripsi, Program Studi Teknologi Hasil Perikanan. Institut Pertanian Bogor.

Sari, M. D. 2008. Pengaruh Penambahan Cao pada Media Budidaya Bersalinitas 4 ppt terhadap Pertumbuhan Hidup Udang Galah (Macrobracium rosenbergii). Skripsi. Institut Pertanian Bogor.

Sukarsa, D. R. 2004. Studi Aktivitas Asam Lemak Omega-3 Ikan Laut pada Mencit Sebagai Model Hewan Percobaan. Jurnal Buletin Teknologi Hasil Perikanan VII (1) : 68-79.

Yustianti, M., N. Ibrahim dan Ruslaini. 2013. Pertumbuhan dan Sintasan Larva Udang Vaname (Litopenaeus vannamei) melalui Subtitusi Tepung Ikan dengan Tepung Usus Ayam. Jurnal Mina Laut Indonesia 1(1) : 93-103. 